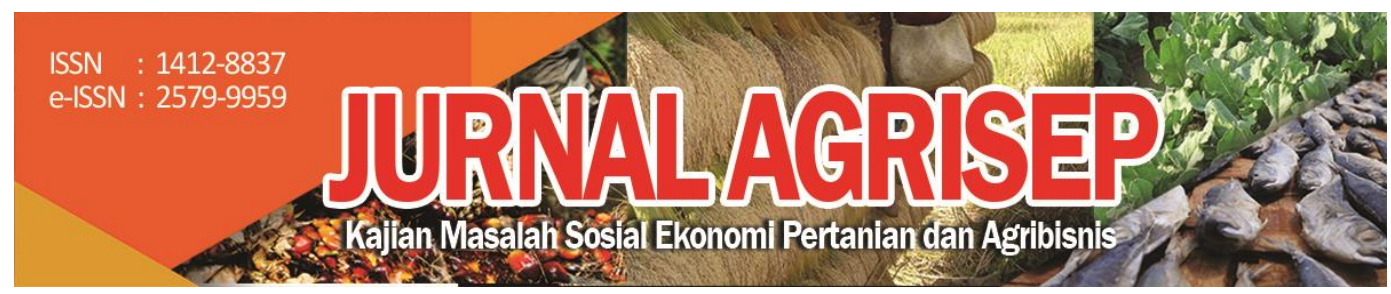

DOI: 10.31186/jagrisep.18.2.219-234

\title{
MODEL PENGELOLAAN SUMBERDAYA ALAM KELAUTAN DENGAN PENDEKATAN SOSIAL EKONOMI
}

\author{
The Marine Natural Resources Management Model with Social \\ Economic Approach
}

\author{
Mochamad Ridwan ${ }^{凶}$; Romi Gunawan \\ Program Studi Ekonomi Pembangunan, Fakultas Ekonomi dan Bisnis, \\ Universitas Bengkulu \\ E-mail: mochamadridwan61@gmail.com
}

\begin{abstract}
This study aims to analyze determinants of management optimization level and build a model relating to the management of marine natural resources/capture fisheries with social economic approach in Bengkulu Province. The types of data collected in this study include primary data (as the main data) and secondary data (as supporting data), which are carried out by interview, questionnaire, focus group discussion, and documentation method. The data analysis method used is descriptive metho and discriminant analysis method. The results showed that through discriminant analysis method, a mathematical (quantitative) model was produced, namely optimization level of marine natural resources management, which was significantly determined by 6 (six) determinant factors including the development of marine natural resource capture method,quality of facilities in TPI (Fish Melting Place), quality of togetherness/participation in marine resource management, quality of ability to market of fish catches, role of local customary institution, and role of government institutions (DKP and OPD related).
\end{abstract}

Keywords: model, management optimization, marine natural resources, social economic approach 


\begin{abstract}
ABSTRAK
Penelitian ini bertujuan untuk menganalisis faktor-faktor penentu tingkat optimalisasi pengelolaan dan membangun sebuah model berkaitan dengan optimalisasi pengelolaan sumberdaya alam kelautan/perikanan tangkap dengan pendekatan sosialekonomi di Provinsi Bengkulu. Jenis data yang dikumpulkan dalam penelitian ini meliputi data primer (sebagai data utama) dan data sekunder (sebagai data penunjang), yang dilakukan dengan metode wawancara, kuesioner, diskusi kelompok terfokus, dan dokumentasi. Metode analisis data yang digunakan adalah metode deskriptif dan metode analisis diskriminan. Hasil penelitian menunjukkan bahwa melalui metode analisis diskriminan, dihasilkan sebuah model matematik (kuantitatif) yaitu faktor tingkat optimalisasi pengelolaan sumberdaya alam kelautan, secara signifikan detentukan oleh 6 (enam) faktor penentu (faktordiskriminan) yaitu perkembangan metode penangkapan sumberdaya alam kelautan, kualitas sarana TPI (Tempat Pelelengan Ikan),kualitas kebersamaan/partisipasi dalam pengelolaan sumberdaya kelautan, kualitas kemampuan memasarkan hasil tangkapan ikan, peran lembaga adat setempat, dan peran lembaga pemerintahan (DKP dan OPD terkait).
\end{abstract}

Katakunci: model, optimalisasi pengelolaan, sumberdaya alam kelautan, pedekatan sosial ekonomi

\title{
PENDAHULUAN
}

Secara empirik, cadangan (stock) sumberdaya alam kelautan/perikanan tangkap di Provinsi Bengkulu, hingga saat ini masih dalam kondisi berlimpah (underfishing). Total potensi sumberdaya alam kelautan/perikanan tangkap ratarata pertahun sebesar 120 ribu ton. Potensi yang sudah tergarap (riil), hingga saat ini baru mencapai kurang dari 50 persen atau sekitar 48 persen. Secara implisit, fenomena ini mengindikasikan bahwa dengan masih besarnya potensi yang dimiliki (underfishing), berarti dalam jangka panjang masih terdapat harapan yang besar untuk dapat mengoptimalkan hasil pengelolaan sumberdaya alam kelautan/perikanan tangkap tersebut secara berkelanjutan (Dinas Kelautan dan Perikanan Provinsi Bengkulu, 2017).

Dalam penelitiannya, Ridwan (2012) telah menemukan terjadinya hubungan kausalitas yang kontradiktif pada beberapa permasalahan seperti rendahnya kemampuan/keterampilan (skill) masyarakat nelayan dalam mengelola sumberdaya alam kelautan/perikanan tangkap, rendahnya kualitas metode penangkapan, rendahnya peran kelembagaan dalam pengelolaan tata niaga perikanan tangkap, dan rendahnya pemahaman (kesadaran) masyarakat nelayan terhadap aspek konservasi lngkungan di sekitarnya. Hasil penelitian terbaru, misalnya penelitian Crawford et al. (2005), Liu et al.( 2007) dan, Ryan et al. (2007) juga menyimpulkan bahwa ekosistem dan bentang alam(Landscapes) adalah sistem manusia-lingkungan yang kompleks, memiliki dinamika yang ditandai oleh ketidakpastian, efek ambang batas, dan pola-pola yang muncul 
yang timbul dari berbagai proses yang saling berhubungan yang dihubungkan lintas skala ruang dan waktu. Permasalahan-permasalahan tersebut juga didukung oleh beberapa hasil penelitian lain seperti hasil penelitian Rahim (2013); Febrianto dkk.(2015); dan Kurniawan dan Erlina (2016).

Secara konseptual, kondisi kontradiktif tersebut sebelumnya telah disitir oleh Gordon (1954) dalam Fauzi (2006). Dengan pendekatan ekonomi, Gordon menjelaskan bahwa sumberdaya alam kelautan/perikanan tangkap akan mengalami tangkap lebih secara ekonomi (economic overfishing) dan lama-lama menjadi musnah, jika pengelolaannya tidak diatur dan tidak dikendalikan secara baik. Fenomena ini terjadi karena sumberdaya alam kelautan/perikanan tangkap tidak seperti sumberdaya alam pertanian atau peternakan yang sifat kepemilikannya cukup jelas. Sumberdaya alam kelautan/perikanan tangkap merupakan sumberdaya alam milik umum (common natural resouces) atau mempunyai sifat akses terbuka (open access), artinya semua individu dalam masyarakat dapat mengakses atau mengeksploitasi sumberdaya alam kelautan/perikanan tangkap tanpa ada batasan. Penelitian sebelumnya juga memperkuat pernyataan dari Gordon (1954), seperti hasil penelitian Taufik (2013), yang menjelaskan bahwa pengelolaan yang integratif antara masyarakat nelayan dengan pemerintah dalam pengelolaan sumberdaya alam kelautan/perikanan tangkap telah menghasilkan kehidupan sosial ekonomi masyarakat nelayan yang lebih baik.

Permasalahan ketidakoptimalan hasil pengelolaan, yang diakibatkan oleh ketidakmampuan masyarakat nelayan dalam mengelola sumberdaya alam kelautan/perikanan tangkap yang dimiliki Provinsi Bengkulu, mengakibatkan rendahnya kinerja produksi yang dihasilkan. Data dari Badan Pusat Statistik Provinsi Bengkulu (2018) menunjukkan bahwa kontribusi subsektor perikanan tangkap terhadap PDRB Provinsi Bengkulu masih jauh dari kondisi optimal atau secara kuantitatif nilainya masih tergolong rendah/sekitar 5 persen. Nilai kontribusi produksi ini ternyata paling rendah bila dibandingkan dengan provinsi-provinsi lain yang ada di pulau Sumatera (Badan Pusat Statistik Indonesia, 2017). Permasalahan inilah yang menjadi penting untuk dilakukan studi yang mendalam, guna menjawab pertanyaan-pertanyaan penting seperti: mengapa ketidakoptimalan pengelolaan sumberdaya alam/perikanan tangkap bisa terjadi, faktor-faktor apa saja yang menjadi penentunya, dan model pengelolaan yang bagaimana yang mampu meningkatkan optimalisasi hasil produksi. Dengan demikian, tujuan dari penelitian ini adalah untuk menemukenali faktor-faktor yang memperngaruhi ketidakoptimalan pengelolaan sumberdaya perikanan tangkap serta merancang model pengelolaan sumberdaya guna mengoptimalkan hasil tangkapan. 


\section{METODE PENELITIAN}

Penelitian ini dilakukan dengan pendekatan deduktif, yakni proses penelitian dilaksanakan berdasarkan teori-teori yang telah ada, yang kemudian dijustifikasi ke dalam permasalahan yang diteliti yaitu mencakup permasalahan optimalisasi pengelolaan sumberdaya alam kelautan khususnya yang ada di Bengkulu. Ada 22 variabel yang digunakan dalam penelitian ini yaitu 1 (satu) variabel terikat (tingkat optimalisasi pengelolaan sumberdaya alam kelautan) dan 21(duapuluh satu) variabel bebas atau variabel penentu.

Jenis data yang digunakan dalam penelitian ini meliputi data primer (sebagai data utama) dan data sekunder (sebagai data penunjang). Data primer dari penelitian bersumber dari data lapangan atau yang bersumber dari para responden yang tersebar di tiga sampel wilayah (kabupaten/kota) yang ada di wilayah Provinsi Bengkulu yaitu Kabupaten Bengkulu Selatan, Kabupaten Bengkulu Utara, dan Kota Bengkulu. Data sekunder bersumber dari Dinas Kelautan dan Perikanan (DKP) Provinsi Bengkulu, dari tiga sampel wilayah (Kabupaten Bengkulu Selatan, Kabupaten Bengkulu Utara, dan Kota Bengkulu), dan dari Badan Pusat Statistik (Provinsi Bengkulu dan Nasional).

Dalam pengumpulan data (data primer dan sekunder), metode yang digunakan dalam penelitian ini terbagi ke dalam dua kelompok, yaitu:

(1) untuk pengumpulan data primer, metode yang digunakan adalah metode wawancara, kuesioner, pengamatan (observasi), dan diskusi kelompok terfokus; dan

(2) untuk pengumpulan data sekunder, metode yang digunakan adalah metode dokumentasi (pengumpulan data dari berbagai laporan dan informasi sekunder lainnya).

Sampel yang terpilih adalah sampel yang diambil dari masyarakat nelayan, bertempat tinggal di wilayah pesisir (wilayah penelitian), dan didasarkan pada beberapa pertimbangan (misalnya sampel harus dapat berkomunikasi dengan baik, familiar terhadap profesinya sebagai nelayan, dan lain-lain). Dengan pengertian lain, metode pengambilan sampel (sampling method) yang digunakan adalah metode pengambilan sampel bertujuan (purposive sampling method). Sampel yang diambil berjumlah 25 (duapuluh lima) nelayan, yakni terdiri dari tokoh masyarakat nelayan dan beberapa nelayan lainnya yang dianggap representatif.

Metode analisis yang digunakan dalam penelitian ini adalah metode deskriptif (untuk metode analisis kualitatif) dan metode diskriminan (untuk metode analisis kuantitatif) (Ghozali, 2005). Khususnya untuk metode analisis kuantitatif, variabelvariabel yang digunakan terdiri dari 21 (dua puluh satu) variabel bebas (independent variable) dan 1 (satu) variabel terikat (dependent variabel). 21 (dua puluh satu) variabel bebas yang digunakan adalah potensi/cadangan (stock) sumberdaya kelautan/perikanan tangkap (X1), prediksi potensi di sumberdaya kelautan/perikanan tangkap masa depan (X2), metode/cara pengelolaan/penangkapan (X3), perkembangan jumlah kelompok afinitas dalam masyarakat nelayan (X4), tingkat kesesuaian alat tangkap dengan kondisi 
kelautan (X5), kualitas prasarana penangkapan (Dermaga, Kios BBM, dan lain-lain) (X6), kualitas sarana Tempat Pelelangan Ikan/TPI (X7), kualitas sistem pelelangan hasil penangkapan (X8), kualitas pendidikan formal dari nelayan (pengelola sumberdaya kelautan/perikanan tangkap) (X9), kualitas pendidikan non-formal dari nelayan (pengelola sumberdaya kelautan/perikanan tangkap) (X10), pengalaman kerja sebagai nelayan (pengelola sumberdaya kelautan/perikanan tangkap) (X11), kualitas pengelolaan (manajerial) hasil tangkapan (X12), kualitas kerjasama/koordinasi/net-working antar kelompok nelayan (X13), kualitas perilaku/sikap saling percaya (Mutual-trust) dalam kelompok nelayan (X14), kualitas kebersamaan/partisipasi dalam pengelolaan sumberdaya kelautan/perikanan tangkap (X15), kualitas tingkat kearifan lokal dalam pengelolaan sumberdaya kelautan/perikanan tangkap (X16), kualitas/tingkat kemampuan optimalisasi hasil pengelolaan sumberdaya kelautan/perikanan tangkap (X17), kualitas kemampuan memasarkan hasil dilihat dari jangkauannya (lokal, daerah, regional/provinsi, nasional, dan internasional/ekspor) (X18), peran lembaga adat setempat dalam menunjang optimalisasi hasil pengelolaan (X19), peran lembaga perkoperasian perikanan laut (X20), dan peran lembaga/organisasi pemerintahan terkait (Dinas Kelautan dan Perikanan/DKP) (X21). 1 (satu) variabel terikat yang digunakan dalam penelitian ini adalah tingkat optimalisasi pengelolaan sumberdaya alam kelautan/perikanan tangkap (Z).

\section{HASIL DAN PEMBAHASAN}

\section{Perkambangan Produksi Perikanan Tangkap di Sumatera}

Untuk memperkuat analisis model pengelolaan sumberdaya alam kelautan/perikanan tangkap di Provinsi Bengkulu, berikut disajikan perkembangan produksi perikanan tangkap di provinsi-provinsi yang ada di wilayah Pulau Sumatera dari tahun 2012 hingga tahun 2016, seperti yang disajikan pada Tabel 1.

Dari Tabel 1, Provinsi Bengkulu ternyata masih belum mampu mengoptimalkan pengelolaan sumberdaya alam kelautan/perikanan tangkap yang dimiliki. Hal ini nampak dari jumlah produksi perikanan tangkap yang dihasilkan (hingga tahun 2016) masih berada di urutan kedua dari bawah setelah Provinsi Jambi. Kondisi kinerja produksi perikanan tangkap Provinsi Bengkulu yang tidak jauh berbeda dengan Provinsi Jambi ini mengindikasikan masih rendahnya tingkat optimalisasi pengelolaan sumberdaya, kelautan/perikanan tangkap di Provinsi Bengkulu. Kondisi anomalis ini dikuatkan oleh fakta yang menunjukkan bahwa kendati luas wilayah perairan laut (perairan tangkap) yang dimiliki Provinsi Jambi jauh lebih sempit bila dibandingkan dengan Provinsi Bengkulu, ternyata mampu menghasilkan produksi perikanan tangkap yang jauh lebih banyak. 
Tabel 1. Perkembangan Produksi Perikanan di provinsi-provinsi yang ada di Pulau Sumatera tahun 2012 hingga tahun 2016 (dalam satuan ton)

\begin{tabular}{lrrrrr}
\hline Provinsi & \multicolumn{1}{c}{2012} & \multicolumn{1}{c}{2013} & \multicolumn{1}{l}{2014} & \multicolumn{1}{l}{2015} & \multicolumn{1}{l}{2016} \\
\hline Sumatera Utara & 510.552 & 508.359 & 484.313 & 494.724 & 475.638 \\
Sumatera Barat & 197.460 & 211.004 & 214.734 & 204.771 & 200.610 \\
Kep. Bangka Belitung & 202.565 & 199.243 & 203.285 & 139.633 & 189.967 \\
Aceh & 148.765 & 153.692 & 157.944 & 173.034 & 189.261 \\
Lampung & 144.485 & 163.107 & 157.968 & 163.384 & 164.420 \\
Kep.Riau & 95.609 & 140.597 & 139.331 & 149.745 & 151.215 \\
Riau & 147.310 & 93.279 & 107.365 & 105.298 & 102.101 \\
Sumatera Selatan & 44.092 & 44.764 & 48.186 & 61.392 & 69.583 \\
Bengkulu & $\mathbf{4 4 . 5 6 1}$ & $\mathbf{5 0 . 9 1 8}$ & $\mathbf{6 0 . 7 0 5}$ & $\mathbf{6 2 . 2 9 1}$ & $\mathbf{6 2 . 4 2 6}$ \\
Jambi & 46.894 & 47.713 & 48.031 & 43.204 & 47.134 \\
\hline
\end{tabular}

Sumber: Badan Pusat Statistik Indonesia (2017)

\section{Model Matematik Pengaruh Faktor-faktor terhadap Optimalisasi Pengelolaan Sumberdaya Alam Kelautan/Perikanan Tangkap di Provinsi Bengkulu}

Model matematika pengaruh faktor-faktor terhadap optimalisasi sumberdaya alam kelautan/perikanan tangkap, esensinya dibangun oleh 6 (enam) faktor yaitu metode/cara pengelolaan/penangkapan (MET), kualitas sarana Tempat Pelelangan Ikan/TPI (TPI), kualitas kebersamaan/partisipasi masyarakat nelayan (PART), kualitas kemampuan memasarkan hasil dilihat dari jangkauannya (lokal, daerah, regional/provinsi, nasional, dan internasional/ekspor) (PASAR), peran lembaga adat setempat dalam menunjang optimalisasi hasil pengelolaan (INST), dan peran lembaga/organisasi pemerintahan terkait (Dinas Kelautan dan Perikanan/DKP) (DKP). Justifikasi terhadap keenam faktor diskriminan tersebut adalah berdadasarkan hasil perhitungan melalui metode analisis diskriminan, yang menghasilkan nilai signifikansi sebesar 0.000, dengan koefisien Wilks' Lambda sebesar 0.04 (kurang dari 0.05) dan nilai Chi-Square sebesar 64.381.

Secara lebih detail, hasil perhitungan (komputerisasi) tingkat signifikansi keenam diskriminator dapat dilihat pada Tabel 2.

224 | Muhammad Ridwan; Romi Gunawan ; Model Pengelolan Sumberdaya ... 
Tabel 2: Koefisien Kanonikal Fungsi Diskriminan (Variabel-variabel yang secara signifikan berpengaruh)

\begin{tabular}{cc}
\hline Variabel-Variabel Diskriminan & Nilai Koefisien \\
\hline X3 & 4.824 \\
X7 & 1.098 \\
X15 & 0.919 \\
X18 & 1.370 \\
X19 & -1.078 \\
X21 & 2.400 \\
KONSTANTA & -24.529 \\
\hline
\end{tabular}

Sumber: Data Hasil Perhitungan (Komputerisasi) yang diolah

Berdasarkan Tabel 2, dapat dibuat persamaan/model matematika dari variabel-variabel bebas (independent variable) yang dapat/mampu menentukan variabel dependennya secara signifikan, yaitu:

$Z=-24.529+4.824 X_{3}+1.098 X_{7}+0.919 X_{15}+1.370 X_{18}-1.078 X_{19}+2.400 X_{21}$

Selanjutnya, model matematika tersebut dapat dinyatakan secara grafik melaui Gambar 1. Berdasarkan Gambar 1, secara eksplisit ada satu hubungan kausalitas (hubungan sebab-akibat)/pengaruh yang kontradiktif (bertanda negatif), yang keberadaannya terlihat pada pengaruh Variabel Peran Lembaga Adat Setempat (X19) terhadap Variabel Tingkat optimalisasi pengelolaan sumberdaya alam kelautan/perikanan tangkap (Z). Variabel-variabel yang lain atau variabel selain X19 (X3, X7, X15, X18, dan X21) berpengaruh linear (positif). Fenomena ini dapat dimaknai bahwa dari hasil penelitian telah ditemukan satu hubungan kausalitas yang tidak sesuai dengan teori yang ada. Dengan pengertian lain, secara teoritik semestinya hubungan kausalitas ini bertanda positif (linear), bukan bertanda negatif (terbalik). Bentuk hubungan kausalitas yang terbalik/anomalistik ini dapat diinterpretasikan bahwa kendatipun peran lembaga adat setempat (X19) semakin menurun, tingkat keoptimalan pengelolaan sumberdaya alam kelautan/perikanan tangkap (Z) tetap meningkat. 


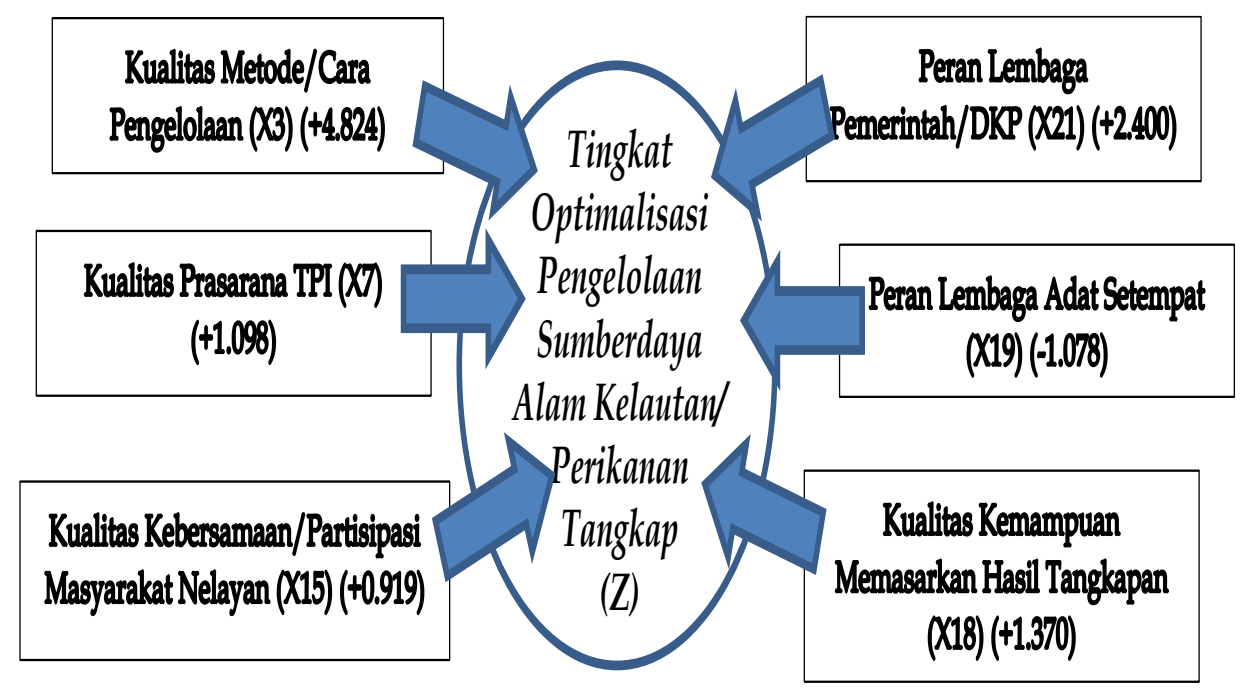

Gambar 1.

Model Grafik dari Fungsi Diskriminan

$$
Z=f(X 3, X 7, X 15, X 18, X 19, X 21)
$$

Analisis Sosial-Ekonomi Faktor-Faktor Yang Mempengaruhi Tingkat Optimalisasi Pengelolaan Sumberdaya Alam Kelautan/Perikanan Tangkap

Tingkat optimalisasi hasil pengelolaan sumberdaya alam kelautan/perikanan tangkap (Z), salah satunya ditentukan oleh transformasi (peningkatan kualitas) dari metode/cara penangkapan sumberdaya alam kelautan/perikanan tangkap (X3). Hasil perhitungan menunjukkan koefisien diskriminan bertanda positif/linear sebesar 4.824. Hubungan kausalitas ini dapat dimaknai bahwa dengan melakukan transformasi atau meningkatkan kualitas metode atau cara yang digunakan dalam proses penangkapan, maka hasil dari pengelolaan (tangkap ikan) semakin optimal. Transformasi ini bisa berupa transformasi teknologi penangkapan (transformasi metode/cara penangkapan dari tingkat tradisional, semi tradisional, hingga modern). Hasil penelitian ini didukung oleh hasil penelitian Kurniawan dan Erlina (2016) serta memperkuat teori peningkatan produktivitas/efisiensi melalui transformasi teknologi/metode (pengembangan teknologi). Dengan melakukan transformasi (perubahan teknologi) ke arah yang lebih tepat, pada gilirannya akan mampu meningkatkan produktivitas kerja nelayan melalui peningkatan produksi (hasil tangkapan ikan) (Case and Fair, 2003). Dengan memodifikasi konsep Case and Fair (2003), maka dari hasil penelitian dapat dibuat model peningkatan total produksi/TP (dari $\mathrm{TP}$ ke $\mathrm{TP}^{\prime}$ ) sebagai akibat dari transformasi teknologi/metode/cara penangkapan sumberdaya kelautan/perikanan tangkap yang lebih baik melalui Gambar 2. 


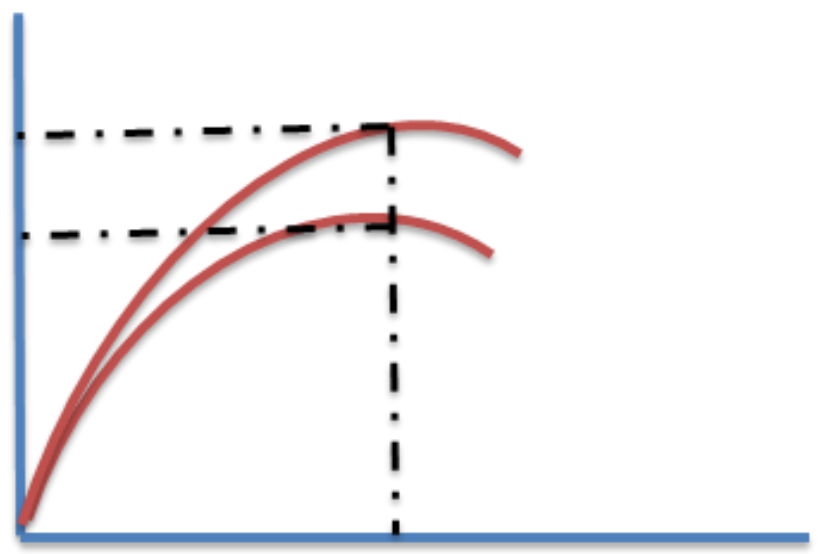

Gambar 2.

Peningkatan Produksi Sumberdaya Alam Kelautan/Perikanan Tangkap melalui Transformasi Teknologi/Metode

Hasil penelitian empiris yang menunjukkan peningkatan hasil tangkapan akibat transformasi teknologi/metode penangkapan ini, ternyata seiring dengan teori/model pertumbuhan logistik (logistic growth model). Model ini menjelaskan bahwa hasil produksi dari aktivitas eksploitasi perikanan tangkap ( $h$ ) merupakan fungsi dari upaya $(E)$ dan cadangan (stock) ikan $(x)$ atau dalam model matematika adalah $h=f(x, E)$. Teori/model ini menjelaskan bahwa hasil produksi perikanan tangkap akan bisa ditingkatkan melalui transformasi/peningkatan kualitas upaya (effort/E) yang diwujudkan melalui peningkatan kualitas teknologi/metode tangkap (alat tangkap), kualitas armada tangkap, dan lain-lain (Fauzi, 2006; Fauzi dan Anna, 2005).

Hasil penelitian empiris juga menunjukkan bahwa koefisien diskriminan dari X7 (Kualitas prasarana Tempat Pelelengan Ikan/TPI) bertanda positif/linear, sebesar 1.098. Tanda positif ini dapat diartikan bahwa fungsi TPI disamping sebagai tempat persandaran kapal-kapal, secara esensial TPI berfungsi sebagai tempat/wadah untuk pelelangan hasil tangkapan perikanan laut, yang sekaligus sebagai pasar hasil tangkapan perikanan laut. TPI merupakan titik pertemuan antara sisi penawaran dan sisi permintaan pada mekanisme pasar/terbentuknya harga pasar/harga keseimbangan. Semakin cepat dan semakin sempurna terbentuknya harga pasar, maka akan memberi rangsangan yang kuat bagi para nelayan untuk meningkatkan motivasi dan semangat dalam aktivitas penangkapan, yang selanjutnya berimplikasi terhadap peningkatan kinerja nelayan berupa peningkatan optimalisasi hasil tangkapan. Hasil temuan penelitian ini sesungguhnya merupakan sebuah pembuktian terhadap sebuah teori motivasi yang mengatakan bahwa semakin tinggi/kuat motivasi seseorang, akan semakin tinggi kemampuan orang itu untuk meningkatkan kinerjanya. Secara matematis, teori motivasi tersebut tulis dalam sebuah model yaitu Kinerja = f (Motivasi) (Feldman, 1988). Hasil penelitian ini 
juga telah dikuatkan oleh hasil penelitian Ridwan dkk. (2009) yang menunjukkan bahwa pemberdayaan melalui suntikan dana untuk kelompok nelayan kecil (tradisional), telah meningkatkan motivasi mereka, yang selanjutnya meningkatkan.

Hasil penelitian juga menemukan tingkat optimalisasi hasil pengelolaan sumberdaya alam kelautan/perikanan tangkap (Z) ditentukan secara signifikan oleh kualitas perilaku/sikap kebersamaan/partisipasi dalam masyarakat nelayan (X15). Hubungan kausalitasnya bertanda positif/linear (koefisien diskriminannya bertanda positif). Tanda positif ini memberi makna bahwa semakin bagus atau semakin kuat tingkat kebersamaan/partisipasi dalam masyarakat nelayan, upaya untuk mewujudkan hasil yang optimal akan semakin mudah dan cepat terwujud. Sebaliknya, semakin jelek atau semakin lemah tingkat kebersamaan/partisipasi dalam masyarakat nelayan, upaya untuk mewujudkan hasil yang optimal akan semakin sulit atau semakin lambat. Dalam konteks optimalisasi hasil, peranan variabel kualitas perilaku/sikap kebersamaan dalam masyarakat nelayan adalah sangat penting dan strategis. Hasil temuan penelitian ini membuktikan sebuah teori modal sosial (social capital theory), yang mengatakan bahwa sikap kebersamaan atau partisipasi yang tinggi merupakan salah satu unsur dalam modal sosial (social capital) yang sangat penting peranannya dalam mewujudkan keberhasilan tujuan kelompok (dalam konteks penelitian merupakan kelompok nelayan yang menjalankan aktivitasnya untuk mengupayakan optimalisasi hasil pengelolaan sumberdaya kelautan/perikanan tangkap) (Dasgupta and Ismail, 1999; Ridwan, 2012).

Koefisien diskriminan bertanda positif/linear juga ditemukan pada hubungan kausalitas dari X18 (Tingkat kemampuan memasarkan hasil tangkapan sumberdaya kelautan/perikanan tangkap dilihat dari jangkauannya yaitu tingkat lokal, daerah, regional/provinsi, nasional, dan internasional/ekspor) terhadap tingkat optimalisasi pengelolaan sumberdaya alam kelautan/perikanan tangkap (Z). Fenomena ini dapat diartikan bahwa jika tingkat kemampuan memasarkan hasil dapat meningkat sampai ke pasar tingkat nasional bahkan ke pasar tingkat internasional/ekspor, maka konsekuensi yang akan diperoleh adalah akan meningkatkan motivasi kerja nelayan, yang berakhir pada peningkatan kinerja nelayan dengan diwujudkan melalui peningkatan optimalisasi pengelolaan sumberdaya kelautan/perikanan tangkap secara signifikan. Pencapaian pemasaran hasil sampai ke tingkat internasional/ekspor tidaklah mudah dan membutuhkan beberapa persyaratan yang ketat, baik yang nampak (observable) maupun yang tidak nampak (unobservable). Implikasi dari kondisi ini adalah urgensi atau kebutuhan yang mendesak akan komitmen yang kuat dari Pemerintah sebagai pemangku kepentingan utama (main stakeholder) untuk segera mengimplementasikan berbagai kebijakan dan program berkaitan dengan upaya pemberdayaan masyarakat nelayan secara terpadu. Hasil temuan penelitian ini membuktikan/mendukung teori ekonomi kelembagaan (economics 
institutional theory) yang memberi penekanan pentingnya peningkatan kerjasama (salah satu unsur modal sosial) dalam bentuk pemasaran hasil tangkapan yang lebih luas, guna memacu motivasi nelayan ke arah peningkatan kinerja (optimalisasi hasil pengelolaan) (Fukuyama, 1995; Yusuf dkk., 2017).

Koefisien diskriminan temuan terakhir yang mempunyai hubungan kausalitas positif/linear adalah X21 (Peran lembaga pemerintah seperti DKP). Tanda positif ini mempunyai arti bahwa peran strategis dari Lembaga Pemerintah (DKP/Dinas Kelautan dan Perikanan di tingkat provinsi dan tingkat kabupaten/kota) dalam memberdayakan masyarakat nelayan adalah sangat penting., karena dapat meningkatkan kemampuan mengoptimalkan pengelolaan sumberdaya alam kelautan/perikanan tangkap yang ada. Bukti empiris terlihat pada peranan DKP Provinsi Bengkulu dalam mengoptimalkan pengelolaan sumberdaya alam kelautan/perikanan tangkap, yang keduanya (antara peran DKP dan hasil optimalisasi pengelolaan) menunujukkan posisi masih rendah. Fenomena pentingnya peran pemerintah (DKP) ini telah disitir juga dalam penelitian Taufik (2013). Hasil temuan empirik ini, secara tidak langsung telah menguatkan teori dari Gordon (1954) dalam Fauzi, 2006).

Satu-satunya koefisien diskriminan yang bertanda negatif/kontradiktif, namun mempunyai hubungan kausalitas yang signifikan adalah Peran Lembaga Adat Setempat (X19). Secara teoritik, koefisien diskriminan sebenarnya bertanda positif, artinya semakin tingginya peran lembaga adat setempat, secara signifikan akan meningkatkan tingkat optimalisasi hasil pengelolaan sumberdaya kelautan/perikanan tangkap (Fukuyama, 1995). Hasil temuan yang menunjukkan hubungan kausalitas yang negatif ini dapat diartikan bahwa peran lembaga adat setempat dalam menunjang optimalisasi hasil pengelolaan sumberdaya kelautan/perikanan tangkap sebenarnya masih ada (dikuatkan oleh hubungan kausalitas/pengaruh yang signifikan), namun dianggap tidak begitu penting dan bahkan sebagian besar masyarakat nelayan sudah tidak lagi memperhatikan aturan-aturan adat setempat (misalnya masyarakat nelayan jika mau melakukan aktivitas kerja sebagai nelayan, mereka sudah tidak lagi memperhatikan nilai-nilai yang berlaku di masyarakat). Kondisi ini disebabkan oleh beberapa faktor seperti pola berfikir masyarakat nelayan yang sudah mulai berfikir secara lebih objektif dan rasional, kendati dengan pendidikan yang relatif masih rendah. Hasil penelitian empirik ini ternyata tidak senada/seiring dengan hasil penelitian Indarti dan Wardana (2013), yang menghasilkan hubungan kausalitas positif danlinear.

\section{Rekonstruksi Model Optimalisasi Pengelolaan Sumberdaya Alam Kelautan/Perikanan Tangkap}

Dimulai dari penemuan 6 (enam) variabel yang secara signifikan menentukan perbedaan tingkat optimalisasi pengelolaan sumberdaya alam kelautan/perikanan tangkap di Provinsi Bengkulu, yang secara grafis telah 
diperlihatkan melalui Gambar 1. Selanjutnya, dengan ditunjang dan dikuatkan hasil penelitian yang lain (Luhur, 2014; Tinambunan, 2016; Qodriyatun, 2013), akhirnya dapat dibangun kembali (rekonstruksi) sebuah model grafis yang menggambarkan sebuah proses mulai dari optimalisasi pengelolaan sumberdaya alam kelautan/perikanan tangkap hingga terbangunnya kondisi kinerja produksi sumberdaya kelautan/perikanan tangkap di Provinsi Bengkulu melalui Gambar 3.

Secara kualitatif, Gambar 3 menunjukkan sebuah model yang menggambarkan proses dari 6 (enam) variabel penentu yang mempengaruhi optimalisasi pengelolaan sumberdaya alam kelautan/perikanan tangkap. Keenam variabel ini merupakan variabel yang sangat penting dan strategis guna mewujudkan kinerja hasil produksi dari pengelolaan sumberdaya kelautan/perikanan tangkap di Provinsi Bengkulu melalui percepatan optimalisasi dari waktu ke waktu secara berkelanjutan. Dalam pengaruhnya baik secara parsial maupun bersama-sama, ke-enam variabel penentu tersebut secara umum bergerak secara linear/positif, kecuali satu variabel yang bergerak secara negatif/kontradiktif, yakni terdapat pada variabel peran lembaga adat setempat.

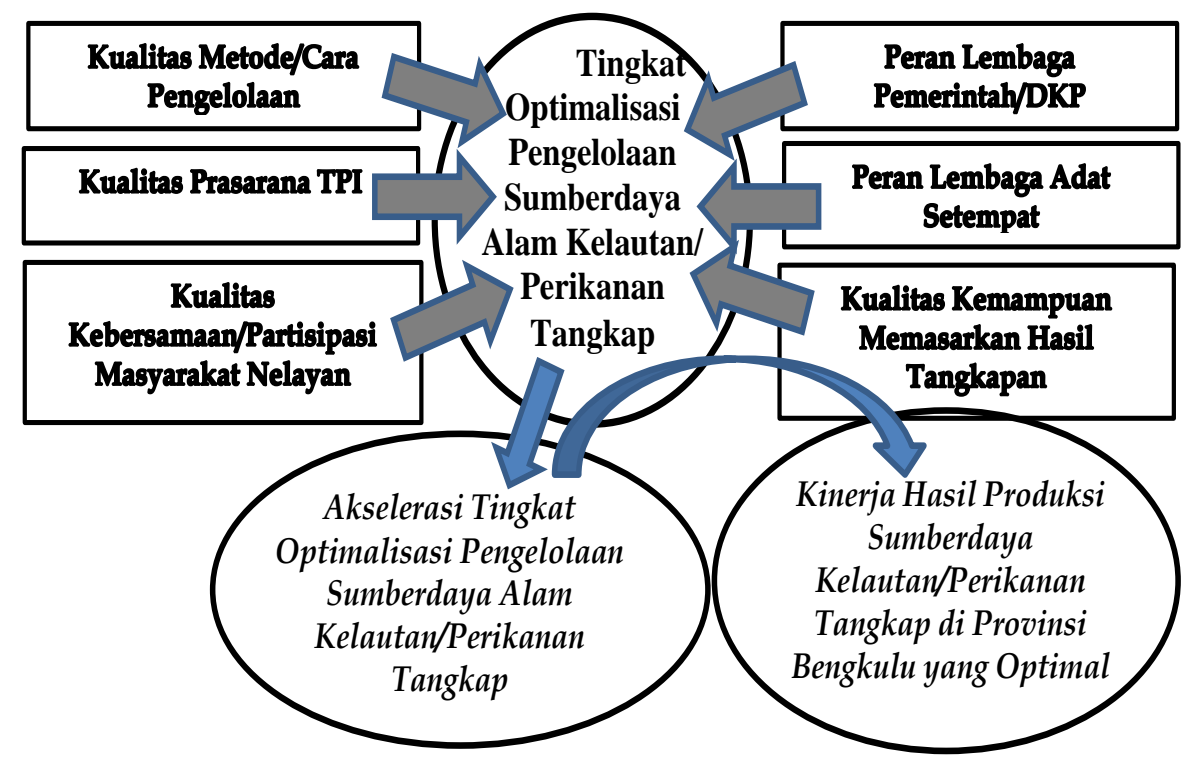

Gambar 3.

Rekonstruksi Model Pengelolaan Sumberdaya Alam Kelautan Perikanan Tangkap di Provinsi Bengkulu 


\section{SIMPULAN DAN SARAN}

\section{Simpulan}

Berdasarkan hasil analisis, dapat dikemukakakn 2 (dua) simpulan, yaitu:

1. Dari hasil analisis kuantitatif dengan metode analisis diskriminan, ditemukan 6 (enam) faktor/variabel yang mempengaruhi/menentukan/ membedakan secara signifikan tingkat optimalisasi pengelolaan sumberdaya alam kelautan/perikanan tangkap, yaitu variabel perkembangan metode penangkapan sumberdaya alam kelautan/perikanan tangkap, kualitas sarana TPI, kualitas kebersamaan/partisipasi masyarakat nelayan, tingkat kemampuan memasaran hasil tangkapan, peran lembaga adat setempat, dan peran lembaga pemerintahan (DKP/Dinas Kelautan dan Perikanan).

2. Konstruksi model yang dibangun memperlihatkan bahwa 6 (enam) faktor penentu tingkat optimalisasi pengelolaan sumberdaya alam kelautan/perikanan tangkap di Provinsi Bengkulu, secara bersama-bersama dan integratif mampu mempengaruhi tingkat optimalisasi pengelolaan. Selanjutnya, faktor ini mampu meningkatkan akselerasi optimalisasi pengelolaan dan berdampak terjadinya keoptimalan kinerja hasil produksi dari sumberdaya kelautan/perikanan tangkap secara berkelanjutan.

\section{Saran} yaitu:

Berdasarkan 2 (dua) simpulan yang ada, dapat dikemukakan 2 (dua) saran,

1. Munculnya satu variabel pengaruh dari 6 (enam) faktor/variabel penelitian yang 'anomalistik' (hasil perhitungan statistik tidak mendukung teori atau hipotesis yang ada), perlu direkomendasikan bagi peneliti selanjutnya untuk melakukan uji dengan ukuran-ukuran yang lain, mengingat ariabel yang dipakai merupakan variabel ekonomi dan sosial, yang biasanya sarat akan unsur subyektivitasnya.

2. Berdasarkan konstruksi model yang dibangun, maka untuk mempercepat akselerasi optimalisasi pengelolaan dan kinerja hasil produksi sumberdaya kelautan/perikanan tangkap, dapat dilakukan beberapa tindakan dalam bentuk program atau kebijakan baik bersifat jangka pendek (short-run) maupun jangka panjang (long-run) sebagai berikut:

a. Dari sisi masyarakat nelayan, dapat dilakukan tindakan revitalisasi, pemberdayaan (empowerment), dan edukasi berupa pelatihanpelatihan praktis berkaitan dengan pengenalan pengetahuan/teknologi perikanan tangkap modern yang sesuai dengan kondisi daerah penangkapan dapat dilakukan oleh fihakfihak yang kompeten;

b. Dari sisi pengguna (perusahaan/korporasi yang bergerak di bidang kelautan/perikanan tangkap), sumberdaya alam 
kelautan/perikanan tangkap merupakan modal utama yang strategis dan prospektif untuk meningkatkan dan mengoptimalkan produksi barang (makanan) turunan berikutnya seperti berbagai makanan kuliner berbahan baku ikan laut, produksi minyak ikan, industri rumah tangga berbahan baku ikan laut, dan lain-lain; dan

c. Melalui instansi-instansi pemerintah terkait seperti BAPPEDA dan Dinas Kelautan/Perikanan, penyusunan perencanaan terpadu segera dilakukan guna pengembangan pengelolaan sumberdaya alam kelautan/perikanan tangkap baik untuk jangka pendek, menengah, maupun panjang.

\section{DAFTAR PUSTAKA}

Badan Pusat Statistik Provinsi Bengkulu. 2018. Bengkulu Dalam Angka Tahun 2017. BPS (Badan Pusat Statistik) Provinsi Bengkulu, Bengkulu.

Badan Pusat Statistik Indonesia. 2017. Indonesia Dalam Angka Tahun 2017. BPS (Badan Pusat Statistik) Indonesia. Jakarta.

Case, Karl E. and Fair, Ray C. 2003. Principles of Economics. Prentice-Hall Inc. New Jersey.

Crawford, T. W., J. P. Messina, S. M. Manson, and D. O'Sullivan. 2005. Complexity science, complex systems, and land-use research. Environment and Planning B: Planning and Design 32:792-798. http://dx.doi.org/10.1068/b3206ed

Dasgupta, P. and Ismail, S. 1999. Economic Progress and the Idea of Social Capital. Washington DC:Word Bank, 325-424. In Elinor Ostrom and T.K. Ahn. 2003.Foundation of Social Capital. Edward Elgar Publishing Limited. Massachusetts.

Dinas Kelautan dan Perikanan (DKP). 2017. Laporan Tahunan Dinas Kelautan EPerikanan Provinsi Bengkulu, Bengkulu.

Fauzi, Ahmad. 2006. Ekonomi Sumberdaya Alam dan Lingkungan:Teori dan Aplikasi, Penerbit PT. Gramedia Pustaka Utama, Jakarta.

Fauzi, Ahmad dan Anna, S. 2005. Permodelan Sumber Daya Perikanan dan Kelautan:Untuk Analisis Kebijakan. Penerbit PT. Gramedia Pustaka Utama, Jakarta.

Febrianto dkk. 2015. Peningkatan Kapasitas Fasilitas Fungsional melalui Program Minapolitan di Pelabuhan Perikanan Nusantara (PPN) Pekalongan Jawa Tengah,Jurnal Kebijakan Sosial Ekonomi Kelautan dan Perikanan, 5(2): 31-42. November 2015.

Feldman, Daniael C. And Arnold, Hugh J. 1988. Managing Individual and Group Behavior in Organization. Mc Graw-Hill International Book Company. Tokyo.

232 | Muhammad Ridwan; Romi Gunawan ; Model Pengelolan Sumberdaya ... 
Fukuyama, F. 1995. Social Capital and The Global Economy, Foreign Affairs, 74 (5): 89-103.

Ghozali, Imam. 2005. Aplikasi Analisis Multivariate dengan Program SPSS. Badan Penerbit Universitas Dipomegoro. Semarang.

Gordon, H.S. 1954. The Economic Theory of a Common Property Resource:the Fishery. Journal of Political Economy, 62:124-142, dalam Fauzi, Ahmad (2006), Ekonomi Sumberdaya Alam dan Lingkungan, Penerbit PT. Gramedia Pustaka Utama, Jakarta.

Indarti, Iin dan Wardana, Dwiyadi Surya. 2013. Metode Pemberdayaan Masyarakat Pesisir melalui Penguatan Kelembagaan di Wilayah Pesisir Kota Semarang, Benefit - Jurnal Manajemen dan Bisnis, 17(1):11-20, Juni 2013.

Kurniawan, Tikkyrino dan Erlina, Mei Dwi. 2016. Ketepatgunaan Teknologi Kelautan dan Perikanan yang Diintroduksikan di Kabupaten Indramayu, Jurnal Kebijakan Sosial Ekonomi Kelautan dan Perikanan, 6(1):37-45, Juni 2016.

Liu, J., T. Dietz, S. R. Carpenter, M. Alberti, C. Folke, E. Moran, A. N. Pell, P. Deadman, T. Kratz, J. Lubchenco, and others. 2007a. Complexity of coupled human and natural systems. Science 317:1513-1516.

Luhur, Estu Sri. 2014. Analisis Konektivitas Kelautan dan Perikanan Antar Wilayah Pulau Utama di Indonesia, Jurnal Kebijakan Sosial Ekonomi Kelautan dan Perikanan, 4(1): 31 - 42, Juni 2014.

Qodriyatun, Sri Nurhayati. 2013. Peningkatan Kesejahteraan Masyarakat Pesisir di Kota Batam melalui Pemberdayaan Masyarakat, Jurnal Aspirasi, 4(2): 91-100 Desember 2013.

Rahim, Abd. 2016. Komparasi Hasil Tangkapan Nelayan Tradisional Wilayah Pesisir Pantai Barat Kabupaten Barru, Jurnal Kebijakan Sosial Ekonomi Kelautan dan Perikanan, 3(2):87-92, Februari 2016.

Ridwan, Mochamad, dkk. 2009. Sintese Model Pemberdayaan Alternatif melalui Penggalian Potensi Kelompok Afinitas:Upaya Pengentasan Kemiskinan Masyarakat Pesisir Di Kota Bengkulu, Penelitian Tidak dipublikasikan, FEB - Universitas Bengkulu, Bengkulu.

Ridwan, Mochamad. 2012. Penguatan Ekonomi Masyarakat Berbasis Kelompok,Jurnal Ekonomi Pembangunan (UMS), 13(2): 207-217, Desember 2012.

Ryan, J. G., J. A. Ludwig, and C. A. Mcalpine. 2007. Complex adaptive landscapes (CAL): a conceptual framework of multifunctional, non-linear ecohydrological feedback systems. Ecological Complexity 4:113-127. http://dx.doi.org/10.1016/ j.ecocom.2007.03.004

Saptanto, Subchechanis dkk. 2017. Analisis Penentuan Indikator Kunci dalam Penghitungan Indeks Kesejahteraan Masyarakat Kelautan dan 
Perikanan, Jurnal Kebijakan Sosial Ekonomi Kelautan dan Perikanan, 7(1):112, Juni 2017.

Taufik. 2013. Analisis Peran Pemerintah Daerah dalam Pemberdayaan Masyarakat Pesisir di Kecamatan Polewali Kabupaten Polewali Mandar, Government: Jurnal Ilmu Pemerintahan, 6(1)61-70. Januari 2013.

Tinambunan, Hezron Sabar Rotua.2016. Pemberdayaan Masyarakat Desa Pesisir melalui Penguatan Budaya Maritim dalam Menghadapi Pasar Bebas Masyarakat Ekonomi Asean, Fiat Justisia Journal of Law, 10(1): 15-33, January-March 2016.

Yusuf R., Freshty Yulia Arthatiani dan Hertria Maharani Putri 2017. Kinerja Ekspor Tuna Indonesia:Suatu Pendekatan Analisis Bayesian, Jurnal Kebijakan Sosial Ekonomi Kelautan dan Perikanan, 7(1): 17-24, Juni 2017. 